\title{
İman Kavramı Üzerine
}

\author{
MUAMMER ESEN
}

DOÇ. DR., ANKARA Ü. İLAHIYAT FAKÜLTESI

e-posta: esen@divinity.ankara.edu.tr

\begin{abstract}
On the Concept of Iman. Faith (iman) means to affirm and verify the truth of someone's report in total trust. The concept of tasdiq, which holds the sense of sincere appropriation and acceptance in addition to its meaning of affirming necessary knowledge or reasoning (nazar) and the knowledge inferred from evidence (istidlal), occupies a significant place in the definition of iman. Having also the cognitive and existential aspects that include a candid embracement, faith is a phenomenon that takes place and is felt in the heart. Therefore, what is essential in iman is the affirmation of the heart. Reason and the term qalb that occurs in the Qur'an are almost identical terms. For this reason, there is a strong relationship between faith, reason, and knowledge.
\end{abstract}

key words

Faith (iman), affirmation (tasdiq), heart, reason, knowledge, deeds ('amal)

Sözlükte "güvenmek, emin olmak, güven içinde bulunmak; inanılır, güvenilir olmak" anlamındaki emn (emân) kökünden türeyen iman (faith, 1branice emunah) kelimesi, birine güvenmek, güven duygusu içinde birini, birinin sözünü doğrulamak, sözünün doğruluğunu onaylamak (tasdik) demektir. ${ }^{1}$

Esasen iman, Arapça'da, yukarıdaki söz konusu anlamları da içererek bir şekilde tam bir güven duygusu içinde birinin sözünün doğruluğunu onaylamak (tasdik) ve ona inanmaktır. Arap dilbilim uzmanlarının üzerinde ittifak ettiği anlama göre de iman, tasdik, yani, doğrulamak, bir sözün doğruluğunu onaylamaktır. ${ }^{2}$

1 Bkz. Cevherî, İsmail b. Hammad, es-Sthah, Dâru'l-İlm, Beyrut 1979, V/2071; Fîrûzâbâdî, Mecduddin Muhammed b. Yakûb, Kâmûsu'-Muhît, Beyrut 1987, s. 1518, İbn Manzûr, Lisânuq-Arab, Beyrut 1970, I/107.

2 Bkz. İbn Manzûr, Lisânuq-Arab, I/107; Cüveynî, İmâmu'l Haremeyn Abdulmelik, AkîdetünnNizâmiyye, (neşr. Muhammed ez-Zebîdî), Dârü'n-Nefâis, Beyrut 2003,s.257; Cüveynî, İmâmu'l-Haremeyn, Kitâbu'l-İrşâd, (neşr. Muhammed Yûsuf Musâ - Ali Abdulmunìm Abdulhamîd), 
İslam'ın yüce peygamberi Hz. Muhammed'den ve onun tebliğ ettiği ilâhî kitab Kur'an nâzil olmadan önceki dönemlerde Araplar imanı, tasdik olarak biliyorlardı. ${ }^{3}$ Nitekim Kur'an'da geçen bir âyette Hz. Yakub'un oğulları, kardeşleri Yusufu kuyuya attıktan sonra akşamleyin babalarına gelip onu bir kurdun yediğini haber vererek ona, "Ama biz doğruyu söylesek de sen bize inanmazsın"4 şeklindeki ifadeleri de gösteriyor ki iman, birinin/ birilerinin sözünü güven duygusu içinde tasdik etmek demektir. ${ }^{5}$

Iman-tasdik

İman sözcü günün, yukarıda söz konusu edilen bu sözlük anlamına geldiğini söyleyenler sadece Arap dili uzmanları değildir. İslam inancını, onun temel kaynağı Kur'an'a göre sistematize etmeye çalışan pek çok kelâm bilginine göre de iman, kalbin tasdikidir.

"İmam tasdiktir" ifadesini ilk kullanan kişinin Mürcie'den Bişr el-Merîsî (218/833) olduğu belirtilmektedir. ${ }^{6}$ Daha sonra gelen ve Sünnî kelam düşüncesinin en önemli iki kurucu önderi olan Ebu'l-Hasan el-Eş'arî (324/ 936) ile Ebû Mansur el Mâtürîdî (333/944) de imanı, tasdik olarak tanımlamışlardır.7 Söz konusu Sünnî ekolün bu iki önder kelam bilgininin izleyicileri olan Bakıllânî (403/1013), Cüveynî (478/1085), Gazzâlî (505/1111), Nesefî (Ebu'l-Mu'în) (505/1114) gibi İslam kelam düşüncesinin önde gelen bilginleri de imanın "tasdik" demek olduğunu söylemişlerdir. ${ }^{8}$

Her ne kadar Eş'arî öncesi dönemde imanı; niyet, inanç (itikad), bilgi (marifet) ve kesin bilgi (yakîn) diye tanımlayanlar olmuşsa da, ${ }^{9}$ imanın bir

Mektebetu'l-Hanecî, Kahire 1950,s.397; Âmidî, Seyfuddîn, Ebkâru'l-Efkâr fî Usûli‘d-Dîn, (neşr. Ahmed Muhammed el-Mehdî), Kahire 2002,V/9; Îcî, Adududdin Abdurrahman, Mevâkıf, (Seyyid Şerif Cürcânî Şerhi ile birlikte neşr. Abdurrahman Ùmeyra), Dâru'l-Ceyl, Beyrut 1997, III/ 527,533; Taftazânî, Saduddin Mes'ùd b. Ömer, Şerhuq-Akâîdi’n-Nesefiyye, (neşr. Muhammed Adnan Derviş), y.y.t.y., s.186.

3 Bkz. Eşàrî, Ebu'l-Hasan Ali b. İsmail, Kitâbul-Lüma' fi‘r-Red àlâ Ehli' z-Zeyğ vel-Bida' (neşr. Richard J. Mc Carthy), Beyrut 1953, s. 75; Bâkıllânî, Kadı Ebûbekir Muhammed b. Tayyib, Temhîd, (neşr. İmâduddin Ahmed Haydar), Beyrut 1987, s. 389.

4 Yûsuf 12/17.

5 Bakıllânî, a.g.e., s.389-390; Cüveynî, İşâd, s.397; Cüveynî, Akîdetu'n-Nizâmiyye, s.257-258; Âmidî, Ebkârưl-Efkâr, V/9-10.

6 Eş'arî, Ebu'l-Hasan, Makâlâtu'l-İslâmiyyîn, (neşr. Helmut Ritter), Wiesbaden, 1980, s.279.

7 Bkz. Eş'arî, Kitâbu'l-Lüma', s.75; Mâtürîdî, Ebû Mansûr Muihammed b. Mahmûd, Kitâbu'tTevhîd, (neşr. Fethullah Huleyf), İstanbul, 1979, s.377; Mâtürîdî, Ebû Mansur Muhammed b. Mahmûd, Te'vilâtu Ehli‘s-Sünne, (neşr. İbrahim Avadayn), Kahire 1971,s.39.

8 Sirasıyla bkz. Bakıllânî, Temhîd, s.389-390; Cüveynî, İşâd, s.397; Cüveynî, Akîdetu'n-Nizâmiyye, s.257-258; Gazâlî, Ebu Hâmid, Faysalu't-Tefrika, (neşr. Mustafa el-Kabbânî),Kahire 1901,s.34; Nesefî, Ebu'l-Mu'în Meymûn b. Muhammed, Tabsiratu'l-Edille fî Usûli‘d-Din, (neşr. Claude Seleme), Dimeşk 1990, I/25-26.

9 Geniş bilgi için bkz. Kutlu, Sönmez, İslam Düşüncesinde İlk Gelenekciler, Kitabiyât, Ankara, 2000, s.81 vd. 
tasdik olduğu görüşü baskın çıkmış ve bu durum, İbn Teymiye'ye kadar eleştirilmeksizin devam edegelmiştir. ${ }^{10}$ İbn Teymiye, Allah sevgisi, Allah korkusu, Allah'a güven gibi kalbin eylemlerinin varoluşsal temellerini oluşturan unsurları yeterince içermediği, onları tam olarak ifade etmediği gerekçesiyle, imanın sadece tasdikle tanımlanamayacağına vurgu yapmaktadır. ${ }^{11}$

\section{Tasdik}

İman, tasdik olduğuna göre, "tasdik"in ne olduğunu, ne anlama geldiğini ortaya koymak gerekmektedir.

İmanın, kendisi marifetiyle tanımlandığ 1 tasdik, herhangi bir haberi haber verenin haberini, hükmünü, samimi bir benimseme ile kesin olarak kabul edip; haberi ve haberin sahibini yalanlamaktan emin kılmaktır. Tasdikin hakikatı, haberin ve haber verenin doğruluğu ile ilgili içten samimi bir benimseme ve kabul olmaksızın kalp(akıl)de meydana gelen bir nispet onaylaması değildir; aksine tasdik, "teslim olmak" anlamına gelecek bir şekil ve ölçüde içten samimi bir benimseme (iz'an) ve kabuldür. ${ }^{12}$ Dolay1syyla iman, salt teorik tasdiki bir bilgi değil; onu da aşan, içinde teslimiyeti, samimi bir benimsemeyi de içeren ve bu yönüyle de bilişsel ve varoluşsal boyutları olan bir gerçekliktir.

Her ne kadar tasdikin sadece bilişsel değil, varoluşsal bir boyutunun olması gerektiği de ortada ise de, imanı tanımlayan tasdikde yine de asıl olan, bilişsel bir temele dayalı bir tasdikin olmasıdır. Dolayısıyla tasdik, zorunlu bir bilgiyi ya da akıl yürütmeye, delile dayalı çıkarımsal (istidlâlî) bir bilgiyi tasdik etmektir. Körü körüne, herhangi bir bilgi ve delile dayanmaksızın bir haberi, bir önermeyi kabul etmek demek, imanda olması gereken tasdik olamaz. Çünkü bilgisiz bir tasdik olmaz; olursa bu, herhangi bir delil olmaksızın körü körüne soyut bir iman olur. Nitekim Cüveynî de tasdikte bilginin önemine değinerek, tasdikin ancak bilgi ile beraber sabit olacağına vurgu yapmıştır. ${ }^{13}$

Imanın (tasdikin) Yeri

Daha önce belirttiğimiz üzere, imanı tasdik kavramı ile tanımlayanlar, bazen söz konusu bu iman tanımlarına kalbi de ekleyerek, imanı, "iman kalp

10 Smith, Wilfred Cantwel, "Faith as Tasdiq", İslamic Philosophical Theology, (ed.Parviz Morewedge), Albany, 1979,s.114.

11 Geniş bilgi için bkz.İbn Teymiye, İman Üzerine, (çev. Salih Uçan) Pınar yayınları, İstanbul 1985 , s.111 vd.

12 Bkz. Taftazânî, Şerhul-Akâid, s.187.

13 Cüveynî, İşấd, s.397. 
ile tasdiktir"14 diye de tarif etmektedirler. Bu şekildeki iman tanımlarıyla onlar, iman tanımında, kalbe de yer vermiş olmaktadırlar. Sünnî kelamcıların, imanı, kalbin bir tasdiki olarak değerlendirmelerinin amacı, Kerrâmiye gibi, imanı sadece "dil ile ikrar" olarak tanımlayanların" ${ }^{15}$ onu sadece dilin bir onayı varsaymalarının, imanı tanımlamada yetersiz kaldığını; imanda aslolanın, kalbin tasdiki olduğunu, tasdikin bunu içerdiğini vurgulamak için olmalıdır. Gerçekten de Kur'an'ın pek çok ayetine bakılırsa imanın yerinin kalp olduğu anlaşılmaktadır. ${ }^{16}$ Çünkü kalbin inkârı söz konusu olduğunda dilin ikrarının gerçek bir iman olmayacağı ortadadır. ${ }^{17}$ Kalbin tasdiki imanı oluşturduğuna göre, Kur'an'da geçen "kalp" kavramının neyi ifade ettiğini, neleri içerdiğini bilmemiz gerekmektedir.

\section{Kur'an'da Geçen "Kalp" Kavramının Anlam Kapsamı}

"Kalp" kavramı Kur'an` da pek çok ayette geçmekte olup ${ }^{18}$; söz konusu bu kavram, akıl ve vicdanı da içerecek şekilde orada kullanılmıştır. ${ }^{19}$ Kalbin bir düşünme organı olduğunu belirten ayetler de vardır. ${ }^{20}$ Özellikle Hacc/ 46. ayette geçen kalp, aklın fiiline dayandırılmaktadır. Buna göre kalp, derinlemesine düşünmek, olayların önünü ve arkasını görmek; onların sebep ve hikmetini anlamaktır. ${ }^{21}$

Düşünme aklın bir eylemidir; ancak, aklın yanında diğer duyu organlar1nın da aklî düşünceye katkısı yadsınamaz. Dolayısıyla insanın doğru düşünebilmesi için, beyninin yanı sıra, diğer duyu organlarının da sağlam olması gerekir. Buradan da anlaşılıyor ki kalp kavramı; aklı, akıl yürütmeyi, düşünme ve anlamayı da kapsayan bir kavram olmasının yanında, bedenin diğer sistemlerini de içine alan insanın biyolojik, fizyolojik, psikolojik, ahlâkî ve entelektüel bütünlüğünü de ifade eden bir kavramdır. Bu nedenle, imanın yerinin kalp olması, aklın devre dışı bırakıldığı anlamına gelmez; bilakis imanın merkezini oluşturan kalp, aklın yanında, insanın tüm iç dünyasını da kapsayan bir kavramdır. ${ }^{22}$

14 Eşàrî'nin tanımı için bkz. İbn Fûrek, Mücerred, s.150-152; ayrıca bkz. Mâtüridî, Kitâbu'tTevhîd, s.373; Âmidî, Ebkâru'l-Efkâr, V/10-11; Taftazânî, Şerhu'l-Akâidi’n-Nesefiyye, s.190191.

15 Bkz. Eş'arî, Makâlâtul-İslamiyyin, s.279 vd.

16 Bkz. Mâide, 5/41; En'âm, 6/125; Nahl, 16/106; Hucurât 49/14; Mücâdele, 58/22.

17 Bkz. İbn Fürek, Mücerred, s.150-152.

18 Yüz yirmi iki ayete bu kavram geçmektedir.

19 Cozo, Muhammed Ali, Mefhûmu'l-Akl vel-Kalb fìl-Kur'ân ve`s-Sünne, Beyrut 1983, s.17.

20 Bkz. A'râf, 7/179; Kâf, 50/37; Muhammed, 47/24.

21 Cozo, Mefhûmul-Akl vel-Kalb, s.188.

22 Geniş bilgi için bkz. Cozo, Mefhûmuql-Akl vel-Kalb, s.45,54; Akbulut, Ahmet, Sahabe Dönemi İktidar Kavgası, y.y.t.y., s.227-228. 
Bununla birlikte, imanın merkezi olan kalp, daha çok, düşünme, bilme, akıl yürütme gibi bilişsel fiillerin merkezi olarak algılanmaktadır. Nitekim çıkarımla (istidlâl) eş anlamlı olarak kullanılan ve bir bilgi elde etme ve akıl yürütme biçimi kabul edilen nazar kavramı, bazı İslam kelam bilginlerince, kalbin hareketi olarak görülmekte; kalbin, delile dayalı çıkarımından (istidlâl), akıl yürütmesi (nazar) ve düşünmesinden (teemmül) bahsedilmekte $^{23}$; "bilginin yerinin kalp olduğu" belirtilmektedir. ${ }^{24}$

İslam'da akılcı düşüncenin mümessili inanç ekollerinden olan Mu'tezîle'nin önde gelen bazı kelam bilginleri de kalbin fonksiyonlarına yönelik önemli hususları dile getirmişlerdir. Nitekim ilk dönem Mu'tezilî bilginlerinden biri olan filozof kelamcı Nazzam,"bilgi"yi, "kalbin bir hareketi" 25 olarak görmektedir. Mu'tezîle'nin son dönemlerinin en önemli temsilcilerinden biri kabul edilen Kadı Abdulcebbar ise, kalp ile yapılan akıl yürütmenin (nazar) çeşitli isimlerinden bahsetmekte; düşünme (tefkîr), incelemearaştırma (bahs) ve geniş, derin ve etraflıca düşünmeyi (teemmül, tedebbür, reviyye), kalp ile yapılan akıl yürütmenin unsurlarından saymaktadır. ${ }^{26}$

Sonuç olarak bütün bu akıl yürütme biçimleri kalb ile ilişkilendirildiğine ve söz konusu bu faaliyetler, aynı zamanda aklın birer eylemi olduğuna göre, buradan da açıkça anlaşılmaktadır ki, imanın merkezi sayılan kalbin akıl ile önemli bir ilişkisi vardır. Dolayısıyla diyebiliriz ki burada söz konusu edilen kalp, bütün bilişsel faaliyetlerin merkezi olan teorik akıldır.

İmanın merkezi kalp; kalp de bir çeşit teorik akıl demek olduğuna göre de, iman ile akıl arasında ayrılmaz bir ilişki olduğu ortaya çıkar ki, bu durumda iman-akıl ilişkisini irdelemek kaçınılmaz olur.

Kalbin, kanıtlarla çıkarımlarda bulunan ve akıl yürütme eylemini gerçekleştiren teorik bir akıl olduğuna değinmiştik. Kur'an'da geçen "Onların kalpleri vardır, onlarla anlamazlar" 27 ; "Yeryüzünde dolaşmazlar mı ki düşünecek kalpleri olsun!" 28 ; "Kur'an üzerinde düşünmüyorlar mı? Yoksa kalpleri kilitli mi!" 29 gibi ayetler de gösteriyor ki, imanın kendisi vasıtasıyla gerçekleştiği, tasdikin merkezi olan kalp, akılla hemen hemen aynı anlamda kullanılmaktadır. Çünkü evren ve evrende olanlar ile Kur'an üzerine düşünüp-

23 Bkz. Bakillânî, Ebûbekir Muhammed b. Tayyib, Temhîdu'l-Evâil ve Telhîsu'd-Delâil, (neşr. Imaduddîn Ahmed Haydar), Beyrut 1987, s.34; Cüveynî, Ebu'l-Maâlî Abdulmelik b. Abdillah, el-Kâfîye fil-Cedel, (neşr. Fevkiye H.Mahmud), Kahire 1979, s.17.

24 Gazâlî, İhyâu Ulûmi‘d-Dîn, (neşr. Seyyid İbrahim, Kahire 1992, III/20.

25 Bağdadî, Ebû Mansûr Abdulkâhir b. Tâhir et-Temîmî, Usûlü‘d-Dîn, Dâru'l-Âfâkı'l-Cedîde, Beyrut 1981, s.6.

26 Kadı Abdulcebbar, Şerhu Usûlil-Hamse, (neşr. Abdulkerim Osman), Kahire 1996,s.45.

27 A'râf, 7/179.

28 Hacc, 22/46.

29 Muhammed, 47/24. 
taşınacak, akıl yürütecek ve böylelikle Tanrı'nın varlığı ve birliği fikrine ulaşacak olan akıldır. Bu akıl, Kur'an'da, daha çok kalp kavramıyla ifade edilmiştir. Zaten Kur'anda doğrudan "akıl" kavramı geçmemekte; onun yerine, "Akledip düşünmüyor musunuz?"30 gibi, onun fonksiyonunu ifade eden ayetler bulunmaktadır. Dolayısıyla Kur'an'ın aklı, fonksiyonel bir akıldır.

\section{Iman-Akıl}

İmanın merkezi sayılan kalbin, akıl yürütme (nazar) ve çıkarımda (istidlâl) bulunma gibi eylemleri göz önüne alındığında, onun, neredeyse akılla aynı anlamda kullanıldığı ortadadır. Bu durum, iman ile akıl arasında sıkı bir ilişkinin olduğunu gösterir. Zira İslam'da, aklı olmayanın dini de olmaz. Çünkü aklını kaybetmiş, düşünemez hale gelmiş biri, dinen sorumlu tutulmaz. Dolayısıyla iman, akla, akıl sahibine hitap eden bir kavramdır. İman konuları akılla bilinebilir ve bu gibi hususların akılla bilinmesine çalışmak, aynı zamanda dinî bir yükümlülüktür. Çünkü Tanrı'nın varlığı, birliği, evrenin Allah tarafından yaratıldığı ve peygamberliğin gerekliliği gibi iman konuları, akla, akıl yürütmeye dayalı kesin delillerle bilinebileceği gibi ${ }^{31}$; esasen Tanrı, bu gibi konularda aklî düşüncenin önemine pek çok ayette vurgu yaparak onu dinî bir vecibe de kılmıştır. ${ }^{32}$

Akıl, iman için gerekli bir şarttır. Akıl olmadan sahih bir imanın gerçekleşmesi mümkün değildir. İnsanın yaratılışı (fıtrat) da esasen bunu gerektirir. Çünkü insan, küfür ve imana sahip olmaksızın yaratılmışır. Tanrı, insana akıl vermesi ile birlikte onu muhatap almış; imanı emredip küfrü yasaklamıştır. Böylece insanlar da, kendilerine bahşedilen akılları sayesinde, kanıtlarıyla birlikte Allah'ın varlığını ve birliğini onaylamışlardır ki, işte bu, onların imanıdır. ${ }^{33}$

İman konusunda akıl o kadar önemlidir ki, vahiy ve peygamber gelmese de, kendilerine dinî tebliğ ulaşmasa da insanların, evrenin yaratılışından v.s. hareketle, akıllarını kullanarak, Allah'ın varlığı ve birliği fikrine ulaşmalarının, onlar için dinî bir yükümlülük (vâcib) olduğu görüşü kabul görmüştür. ${ }^{34}$ Hatta Eş'arîler bile, Allah’ı bilmeye götüren akıl yürütme (nazar) ile delile dayalı çıkarımı (istidlâl), dini bir görev saymışlardır. ${ }^{35}$

30 Bakara, 2/44,76; Enàm, 6/32; A'râf, 7/169; Yûnus, 10/16; Hûd, 11/51; Yûsuf, 12/109; Enbiyâ, 21/10,67; Mü‘minûn, 23/80; Kasas, 28/60; Sâffât, 37/138.

31 Bkz. Mâtürîdî, Kitabü't-Tevhîd, s.9-11, 17-29, 202-209.

32 Bkz. Bakara, 2/164; Fussilet, 41/53; Zâriyât, 51/21.

33 Bkz. Ebû Hanîfe, el-Frkhu'-Ekber, İmam-ı Azam’ın Beş Eseri içinde, (neşr. ve çev. Mustafa Öz), İstanbul 1992, s.56.

34 Bkz. Beyâzîzâde, Ahmed b. Hasan, Usûluq-Munîfe li İmam Ebû Hanîfe, (İmamı Azamìn İtikâdi Görüsleri içinde; neşr. İlyas Celebi), İstanbul 1996, s.79-8.

35 Eş’arî‘nin bu konudaki görüşleri için bkz. İbn fûrek, Mücerred, s.250. Ayrıca bkz. Bakıllânî, Ebûbekir Muhammed b. Tayyib, el-İnsâf, (neşr. M.Zâhidu'l-Kevserî), Kahire 1993 s.25. 
Buradan da anlaşılıyor ki, vahiy ve peygamberler, temel iman konularında insan aklını çalıştırmaya yardımcı olmak ve onu harekete geçirmek amacıyla, Tanrı tarafından insanlara birer lütuf olarak gönderilmişlerdir. Elbette meleklerin varlığ 1 vb. iman konuları da vardır; ancak asıl olan, Allah'ın varlığ 1 ve birliğine (tevhid) olan inançtır ki, esasen akıl bunu tasdik eder; vahiy ise, aklın tasdikine yardımcı olur, ona rehberlik eder.

İman konuları aklî çıkarımlara dayalı bilgilerdir. Dolayısıyla iman bireyseldir, delile dayanması gerekir. Onun dayanağını teşkil eden en önemli deliller ise, akıl yürütmeler sonucunda ulaşılan kesin delillerdir. Çünkü İslam'da iman konuları subjektif kesinlikten daha çok objektif kesinliğe sahiptirler. Zira bunlara, bilgiye dayalı olarak ulaşılır. Dolayısıyla bunlar, epistomolojik değer yüklüdürler.

Sonuç olarak, aklî delillere dayanan objektif kesin bir bilgi sonucu imana ulaşmak, araştırmaya dayalı bir imanın (tahkikî iman) gereğidir ve imanda makbul olan da budur. Herhangi bir araştırmaya, kesin bir bilgiye dayanmadan körü körüne bir iman (taklidî iman), İslâm'ın benimsediği, onayladığı bir iman değildir. Aklın önemini öteleyen fideist bir iman anlayışı, İslam'da benimsenmemiştir. İslam'da aklî delillere dayalı olarak inanmanın teolojik ve aynı zaman da ahlâkî temelleri de söz konusudur. Çünkü insanlar, neye, niçin ve nasıl iman ettiğinden dolayı sorumludurlar. Dolayısıyla onlar, sorumluluklarının gereği olarak, imanlarını, sağlam temellere oturtmak durumundadırlar.

\section{Iman- Bilgi}

İman ile akıl arasındaki ilişkiler açığa çıktıktan sonra, akıl ile ilişkisi ortada olan bilginin, iman ile de ilintili olacağı açıtır.

İslam inanç ekolleri içinde iman tanımları içinde bilgiye en çok yer verenler, şüphesiz Mürciî bilginlerdir. ${ }^{36}$ Bunlar içinde, insanın hür iradesini yok saydığı için Cebrîye'nin de kurucusu sayılan; ancak, iman tanımıyla aynı zamanda Mürcie'nin de önderlerinden kabul edilen Cehm b. Safvân ve takipçileri imanı, sadece Tanrı'yı, elçilerini ve O'ndan gelen her şeyi bilmek olarak tanımlarlar. Dolayısıyla buna göre küfür, Allah'ı bilmemektir. ${ }^{37} \hat{A}$ midî‘nin aktardığına göre, Şia'nın önemli kollarından biri olan İmâmiyye ile bazı İslam fakihlerine göre de iman, Allah'ı bilmektir. ${ }^{38}$

36 Geniş bilgi için bkz. Eş'arî, Makâlât, s. 132-141; Izutsu, Toshihiko, İslam Düşüncesinde İman Kavramı, Pınar Yayınları, İstanbul 1984, s.107.

37 Eşàrî, Makâlât, s. 132,133.

38 Âmidî, Ebkârul-Efkâr, V/7-8. 
İmanı, bilgi (marifet) olarak tanımlamak suretiyle rasyonel bir tutum içine girdikleri sanılan Mürcie'nin bilgi anlayışlarında farklılıklar söz konusudur. Akla (nazar) dayanmayan bir inancin (itikat) bilgi ve iman olupolmayacağı hususunda bunlar iki ayrı görüş içinde olmuşlardır. Bunlardan bir grup, akletme olmaksızın gerçekleşen bir kanaatin iman olmayacağını savunurken; buna karşın diğer bir grup ise, akla dayanmayan bir inancın da iman olduğu görüşündedirler. ${ }^{39}$

İslam inanç sistemi içinde önemli bir yeri olan Ehl-î Sünnet'in önde gelen kelam bilginlerinden biri olan Mâtürîdî, imanı, sadece bilgiden ibaret sayanları eleştirmektir. İman, tasdik; küfür ise, tekzip iken; bilginin zıddı, küfür veya tekzip değil, bilmemektedir(cehâlet). Dolayısıyla bir şeyi bilmeyen bir kimse, onu yalanlama (tekzip) konumunda olamayacağından, böyle birisi, o şeyi tekzip etmekle nitelendirilemez. Bu da gösteriyor ki, iman için bilgiden öte kalple gerçekleşen bir tasdik olgusu söz konusudur. Bununla birlikte, yine de bilgi önemlidir; çünkü bilgi, kalbi tasdike yönelten bir sebeptir. Nitekim çoğunlukla da bilgisizlik, tekzip ve inkâra sevketmektedir. ${ }^{40}$

Mâtürîdî’nin, imanı salt bilgi olarak görenleri eleştirmesi haklı gözükmektedir. Ancak, onun eleştirdiği Cehm b. Safvân, imanı ilimden ibaret sayarken; muhtemelen onun bilgiden kasdı, tasdike sevkeden bir bilgidir. ${ }^{41}$ Zira ibn Teymiye, Cehm'î, imanı tasdik olarak tanımladığı için eleştirmektedir. ${ }^{42}$

Esasen imanda asıl olan tasdik; bir bilginin doğrulanması, doğruluğunun kabul edilmesi anlamında epistomolojik içeriği olan bir tasdik olduğundan; imanı daha çok tasdik olarak tanımlayan Eş'arî inanç ekolünün önde gelenlerinden Cüveynî, kelâm-ı nefs olan tasdikin, ancak bilgi ile sabit olacağına vurgu yapmıştır. ${ }^{43}$ Bu nedenle, imanda söz konusu olan tasdîki salt bir inanç olarak görüp onu bilgi olarak görmemek doğru değildir. Kaldı ki, imanı tasdik olarak tanımlamayı uygun ve yeterli gören Eş'arî ekolünün kurucusu İmam Eş'arî bile imanın, Allah'ı bilmek olduğu üzerinde dururken ${ }^{44}$ bununla ilgili pek çok ayeti de zikretmektedir. ${ }^{45}$ Eş'arî’nin öğrencilerinden ve Sünnî kelamın öncülerinden biri olan Bakıllânî de imanı, yüce

39 Eş'arî, Makâlât, s.144; Esen, Muammer, İman, İmanla İlişkili Kavramlar ve Temel İman Esasları, Araştırma yayınları, Ankara 2006, s.13.

40 Mâtürîdî, Kitâbü'l-Tevhîd. s.380.

41 Mâtürî̀î, Kitâbü'l-Tevhîd. s.380.

42 Bkz. İbn Teymiye, Ebu'l-Abbas Takıyyuddin Ahmed b. Abdilhalîm, Kitâbu'l-Îmân, (neşr. Hâşim Muhammed Şâzelî), Kahire, t.y., s.136-137.

43 Cüveynî, elìirşâd, s. 397.

44 İbn Fûrek, Mücerred, 248-249.

45 Ayetlerle ilgili bkz. Bakara, 2/196,235; Enfal, 8/25; Ra'd, 13/19; Muhammed, 45/19. 
Allah'ı tasdik olarak tanımlarken, imanın/tasdikin, ilim olduğuna ayrıca vurgu yapmaktadır. ${ }^{46}$ Aynı kişi, "el-İnsâf" adlı eserinde ise, Ehl-i Sünnet'e göre imanın bilgi ve kalp ile tasdik olduğunu belirtmektedir. ${ }^{47}$

Eş'arîliğin ilk dönem temsilcilerinden bazılarının iman (tasdik) ve bilgiyi özdeşleştirdiği sezinlenmektedir. Bununla birlikte, onların, imanı, tam bir bilgi olarak mı; yoksa bilgiyi de içeren bir kavram olarak mı tanımladıkları meselesi tartışmalıdır. Rosenthal, Eş’arîlik, Mâtûrîdilik, Mu'tezile gibi pek çok düşünce ekolünün imanı bilgi ile aynı anlamda kullandığına vurgu yaparken; ${ }^{48}$ buna karşın Izutsu'ya göre, özellikle Eş'arîler, imanı, bilgiye dayanan ve fakat onu da aşan iradî (voluntarist) bir tasdik olarak görürler. ${ }^{49}$ Esasen bu tesbit doğrudur; çünkü herhangi bir şey hakkındaki bilgi, sadece bilgi olarak kalır, insanı, kendi özgür iradesine dayalı kesin bir kalbî tasdike götürmezse, o bilgi, tek başına imanı tanımlama da yeterli olamaz. ${ }^{50}$

Esasen tasdik de bilginin bir bölümü bir bilgi türü kabul edildiğine göre, ${ }^{51}$ İslam kelam bilginlerinin imanı tanımlarken kullandıkları bilgi, herhangi kuru bir bilgi değil, delile dayanan bir bilgidir ${ }^{52}$. Bu, aynı zamanda tasdiki bilgidir. İslam kelamcılarının imanı tanımlarken söz konusu ettikleri tasdiki, yani önermesel bilginin zıddı, yanlış inanç demek olan cehalettir (cehl) ki, bu, bilgisizlik değil; tersine, bir şeye olduğundan farklı bir şekilde inanmak (itikad)tır. Aynı zamanda, bu tür bilgi, inançlar arasında tercihte kararsızlığın ifadesi olan şüphe (şekk) ile zanna karşıt bir bilgidir. ${ }^{53}$ Buradan da anlaşılıyor ki, imanın tanımında yer alan bilgi, zan ve şüpheye yer bırakmayacak şekilde kesin delillere dayalı olarak çıkarsanmış, çıkarımsal tasdiki bir bilgi olup, bu, aynı zamanda doğru, kesin inançtır.

Sonuç olarak kesin delillere dayalı tasdiki bir bilginin ifadesi olan iman, şek ve şüpheden uzak olarak kalbin güvenilir bir şekilde tasdik ettiği kesin kalbî/aklî bir bilgidir. Böyle bir bilgi, kesin bir bilinç halini ifade eden, beraberinde kesin bir inancı (iman) doğuran bir bilgidir. Bu tür bir bilgi, kalbin/ aklın tasdîkîne mahzar olmuş, salt bir bilgi olmanın ötesinde kalbin güvenini kazanmış, orada yer edinmiş, doğruluğu kesin kabul görmüş tasdikî bir bilgidir ve imanda esas olan da, işte bu kesin tasdîkî bilgidir.

46 Bakıllanî, el-Temhîd, s.189.

47 Bakillânî, el-İnsâf, s.351-352.

48 Rosenthal, Franz, Knowledge Triumhant: The Concept of Knowledqe in Medieval İslam, Leiden, 1970,s.108.

49 Izutsu, The Concep of Belief in Islamic Theology; A Semantic Analysis of Iman and İslam, Tokyo, 1965, s.137 vd.

50 Bkz. Taftazânî, Şerhull,Akâid, s.198.

51 Bkz. Hanefî, Hasan, Minel-Akîde ilâ's-Sevra, Beyrut 1988, V/37-38.

52 Bkz. Nesefî, Ebu'l-Muîn, Tabsıratu'l-Edille(neşr. Claude Seleme), Dımeşk 1990,I/30.

53 El-Cüveynî, el-İrşâd, s.35-36; İbn Fûrek, Mücerred, s.248. 


\section{Iman-islam}

Sözlükte, esasen bir şeyi, bir bilgiyi doğrulamak, doğruluğunu kabul etmek (tasdik) anlamına gelen "iman" kavramı ile itaat etmek, boyun eğmek, bir şeye teslim olmak, esenlikte kılmak gibi anlamlara gelen "İslam" kavra$\mathrm{m}$, açıkca görüldüğü üzere lafız itibariyle birbirinden farklı iki sözcüktür. ${ }^{54}$ Bununla birlikte, İslam'ın inanç sistemini ilk olarak en derli toplu bir şekilde özetle sunan bilginlerin başında gelen İmamı Azam Ebû Hanife, iman ve İslam'ı, birbirinin içi ve dışı gibi görmekte; İslamsız imanın, imansız da İslam'ın olmayacağına özenle vurgu yapmaktadır. ${ }^{55}$ Buradan da anlaşılıyor ki o, her ne kadar lafız itibariyle iman ile İslam farklı iki sözcük olsa da, temelde aralarında bir fark görmemektedir.

İman ile İslam'ın özdeş olup olmadığı konusu tartışmalı bir konudur. $\mathrm{Bu}$ ikisi arasında fark olduğu düşüncesinde olanlar, bu düşüncelerini, Hucurât (49/14) süresinde geçen bir ayet ile meşhur Cibril hadisine dayanmaktadırlar. Nitekim söz konusu sürede geçen; "Bedevîler, 'inandık' dediler. De ki: 'Siz iman etmediniz, ama boyun eğdik (müslüman olduk)' deyin." sözü, iman henüz kalplerine yerleşmemiş olan bedevilerin "müslüman" olma durumunu ifade etmek üzere kullanılan bir sözdür. Dolayısıyla, iman kalplerine henüz yerleşmemiş olan taşralı bedeviler, sanki mümin olarak değil de müslüman olarak değerlendirilmektedir ki, bu durum, bazı bilginleri, iman ile İslam arsında bir fark olduğu düşüncesine götürmüştür. Aynı şekilde, meşhur "Cibril hadîsi" nde, melek Cebrâil'in Hz. Peygamber'e önce "iman nedir?" diye sorduğu soruya Hz. Peygamber'in; "Allah'a, meleklerine, kitaplarına, peygamberlerine ahiret gününe ve kadere iman etmendir." şeklinde cevap vermesine rağmen O'nun (Cebrail), ayrıca Peygamber'(a.s.)e İslam'ı da sorması, bazı İslam bilginlerini, bu iki kavram arasında fark olduğu düşüncesine sevketmiştir. Çünkü Cebrail'in iman sorusuna yukarıdaki cevabı veren Hz. Peygamber, "İslam nedir?" sorusunu ise; "Allah’tan başka tanrı bulunmadığını ikrar etmen, namaz kılman, zekât vermen, Ramazan orucunu tutman ve Kâbe'yi ziyaret etmendir"s6 diye cevaplamıştır.

İslam ile imanın ayrı ayrı şeyler olduğunu ileri sürenler, işte bu hadisten hareketle, Cebrail'in, imanı sorduktan sonra bununla yetinmeyip ayrıca Is-

54 Bkz. Ebû Hanife, el-Frkhuq-Ekber, Haydarâbad 1342, s.10; Mâtürîdî, Ebû Mansur Muhammed b. Muhammed Mahmud, Şerhuq-fikhıl-Ekber, (neşr. Abdullah b. İbrahim el-Ensârî), Katar, t.y., s.151; Aliyyu'l-Kârî, Şerhu'l-fikhı '-Ekber (neşr. Muhammed Bedreddin), Kahire 1323, s.80-81. 55 Ebû Hanife, el-fikhı'l-Ekber, s.10.

56 Bkz. Buhârî, "Îmân", 37(Buharî'de geçen söz konusu hadîste kadere iman konusu yer almaktadır.); Müslim, "Îmân", I, 6-7; Ebû Dâvûd, "Sünnet", 16; Tirmizî, "Îmân", 4; Nesâ̂̂, "Îmân" 5-6; İbn Mâce, "Mukaddime", 9-10. 
lamı da sormasını, kendi düşüncelerine delil getirmişlerdir. Dolayısıyla, söz konusu ayet ve hadisten de hareketle iman ile İslam arasında bir yönüyle fark bulunduğunu dile getirenlere göre iman, içteki bir olguyu (kalbin tasdiki) ifade ederken; buna karşın İslam, daha çok dıştaki bir olguyu, insanın görünür amellerini ifade etmektedir. ${ }^{57}$

Böyle bile olsa iman ve İslam birbirini tamamlayan, biri olmadan diğerinin anlamı olmayan iki kavramdır. Nitekim "İslam'dan başka bir din arayan kimseden bulacağı hiçbir din kabul edilmeyecektir"ss ayetinde söz konusu edilen İslam, imanı da içeren hatta onunla aynı anlamı taşıyan Allah'ın dininin adıdır. ${ }^{59}$ Bunun gibi, "Sen, ancak ayetlerimize inanip da teslim olanlara duyurabilirsin"60 ayeti de açıkça gösteriyor ki, temelde bu ikisi, aynı ya da en azından birbirine yakın anlamları içeren, ancak lugat bakımından farklı olan iki kavramdır.

Sonuç olarak imanın gereğini yerine getiren kişi, gerçek bir Müslüman olduğu gibi, İslam'ın şartlarını inanarak gereğince yerine getiren kişinin de gerçek bir mümin olduğu kuşkusuzdur. Bu bakımdan son tahlilde iman ve İslam aynı şeyler olmaktadır. Bununla birlikte iman daha öznel, İslam ise daha nesneldir.

Iman - Amel

İman, daha çok içteki /kalpteki bir olguyu, İslam ise daha çok dıştaki bir olguyu, yani insanın görünür amellerini ifade eden kavramlar olduğuna göre, iman ile amel arasında da oldukça sıkı bir ilişkinin olması kaçınılmazdır. Bununla birlikte, hicrî I. asrın ikinci yarısından itibaren iman-amel ilişkisi bağlamındaki tartışmalar hep süregelmiştir.

Hâricîler başta olmak üzere, Mu'tezile ${ }^{61}$ ile Ashâbu'l-hadis'in çoğunlu$\breve{g u}$, ameli, imanın ayrılmaz bir parçası olarak kabul etmişlerdir. ${ }^{62}$ Buna karşın, başta Mürcie olmak üzere, onun, özellikle iman konusundaki görüşleri itibariyle takipçileri olan Ehl-i Sünnet kelamcılarına göre ise iman ve amel ayrı ayrı şeylerdir. Dolayısıyla amel, imanın bir parçası değildir. Bunlara göre, imanın hakikatı tasdik iken, buna karşın amelin hakikatı ise uygula-

57 Bkz. Mâtürîdî, Kitabu't-Tevhid, s.393-394.

58 Âl-i İmrân, 3/85.

59 Daha geniş bilgi için bkz. Mâtürîdî, Kitâbu’t Tevhîd, s. 393.

$60 \mathrm{Neml}, 27 / 81$.

61 Geniş bilgi için bkz. Âmidî, Seyfuddîn, Ebkâru'l-Efkâr fî Usûli'd-Dîn, (neşr. A.M.Mehdî), Kahire 2002, V/8.

62 Buhârî, Ebû Abdillâh Muhammed, el-Câmiu's-Sahîh; Kitabu'l-Îmân, (neşr. S.Kurt), İstanbul $1981, \mathrm{I} / 7$. 
madır. Dolayısıyla aralarında tümel-tikel ilişkisi söz konusu değildir. Yine bunlara göre, Kur'an'da geçen "İman edenler ve salih amel işleyenler" ifadesinde iman ve amel ayrı ayrı zikredilmiştir. Eğer ikisi aynı şey olsaydı "iman edenler" dendikten sonra, ayrıca bir de "salih amel işleyenler" denmesine gerek duyulmazdı. Bunlar ayrıca Kur'an'da geçen "Allah'in mescitlerini, ancak Allah'a, ahiret gününe inanan ve namazı kılan, zekâtı veren..." ifadeyi dayanak göstererek de iman ve amelin ayrı ayrı şeyler olduğunu söylemektedirler. ${ }^{64}$

\section{Sonuç}

Netice itibariyle iman, birinin sözünün/haberinin doğruluğunu tam bir güven duygusu içinde doğrulayıp onaylamak demektir. İman kavramının anlamını ifade etmek üzere onun yerine kullanılan tasdik sözcügüu de esasen zorunlu bir bilgiyi veya akıl yürütme (nazar) ve delile dayalı çıkarımsal (istidlâlî) bir bilgiyi onaylamak anlamına geldiği gibi, içten samimi bir benimseme ve kabul anlamını da içerir. İman, sadece teorik bilgiyi onaylamanın ötesinde, teslimiyet ve samimi bir benimsemeyi içeren bilişsel ve varoluşsal boyutları da olan bir tecrübedir.

İman, kalpte gerçekleşen ve hissedilen bir olgudur ${ }^{65}$. Bu nedenle, imanda asıl olan kalbin onayıdır. Kur'an'da geçen kalp kavramı, akıl kavramı ile hemen hemen özdeştir. Nitekim kalbin bir düşünme organı olduğunu belirten ayetler de vardır ${ }^{66}$. Akıl, iman için gerekli bir şarttır; akıl olmadan sahih bir imanın gerçekleşmesi olanaksızdır. Aklî delillere dayanarak elde edilen objektif kesin bir bilgiden hareketle imana ulaşmak, araştırmaya ve sorgulamaya dayanan bir imanın (tahkiki iman) gereğidir. İslâm'da kabul gören (makbul) iman işte budur. Herhangi bir araştırmaya, kesin bilgiye dayanmayan körü körüne iman (taklidî iman) makbul sayılmaz. Dolayısıyla İslâm, aklın önemini yadsıyan fideist bir iman anlayışını onaylamaz.

İman ile akıl arasındaki ayrılmaz bağ, kaçınılmaz olarak iman-bilgi ilişkisini de gündeme getirir. Öyle ki İslâm inanç ekollerinden bazıları imanı, bilgi; inançsızlığı (küfür) ise Allah'ı bilmemek olarak tanımlamışlardır. İmanı, tasdik olarak tanımlayanlar da imanda bilginin önemini vurgulamışlardır. Çünkü bilgi, kalbi tasdike yönelten bir sebep iken; buna karşın bilgisizlik,

\footnotetext{
63 Tevbe, 9/18.

64 Bkz. Nesefî, Ebul-muîn, et-Temhîd fî Usûli'd-Dîn, (neşr. Abdulhayy Kâbil) Kahire 1987, s. 100; İbn Teymiye, İman, (çev. Cemal Güzel), İstanbul 1996, s. 120-122.

65 Bkz. Mâide, 5/41; En'âm, 6/125; Nahl, 16/106; Hucurât, 49/14; Mücâdele, 58/22.

66 Bkz. A'raf, 7/179; Hacc, 22/46; Muhammed, 47/24; Kaf, 50/37.
} 
çoğunlukla insanı inkâra (küfür) sevk eder. Bu bakımdan bilgi, imandan önce gelir.

İman ile İslâm lafız itibariyle farklı olmakla birlikte, son tahlilde, özdeştirler $^{67}$. Bunlar, birbirinin içi ve dışı gibi olup birbirini tamamlarlar. İman, içteki bir tasdik iken; İslâm, daha çok, onun dıştaki yansımasıdır. Dolayısıyla İslâm, aynı zamanda imanın eyleme dönüşmüş yönü gibidir. Kalbin eylemi olan imanın meyveleri ise, insanlığın yararına uygun, güzel eylemler (ameller) yapmaktır. Nitekim Kur'an'da “İnanıp hayırlı, yararlı işler yapanlar..." ifadesi çokça yer almaktadır ${ }^{68}$.

Özetle iman, Allah'ın varlığını, birliği(tevhid)ni; Elçisini ve O'na getirilenlerin doğruluğunu aklî delillere dayalı olarak onaylamak demektir. Kur'an'da geçen iman konuları; Allah'a, peygamberlere, kitaplara, meleklere ve ahiret gününe imandan oluşur ${ }^{69}$ Bunlara inananlara "mümin" denir. Esasen imanın bu kavramsal tanımı, kelimenin sözlük anlamına da uygun düşmektedir $^{70}$.

67 Bkz. Bakara, 2/136; Yûnus, 10/84; Hucurât, 49/17; Zâriyât, 51/35-36.

68 Bkz. Bakara, 2/25, 82, 277; Âl-i İmran, 3/57; Nisâ, 4/57, 122, 173; Mâide, 5/9, 93.

69 Bkz. Bakara, 2/177, 285.

70 Bkz. Yûsuf, 12/17. 